\title{
BROILER BREEDER HEN PERFORMANCE AND EGG HATCHABILITY DURING RAINY SEASON IN BRAZILIAN SEMI-ARID REGION ${ }^{1}$
}

\author{
DERMEVAL A. FURTADO ${ }^{2}$, LAURA D. C. A. TOTA ${ }^{3}$, JOSÉ W. B. NASCIMENTO ${ }^{4}$, \\ MÉRCIA C. DA C. GUIMARÃES ${ }^{5}$, JOSÉ P. LOPES NETO ${ }^{6}$
}

\begin{abstract}
Henhouse thermal comfort and bird age influence broiler breeder hen productivity; this way, the present research aimed to assess thermal comfort indexes and broiler breeder hen performance during winter in North East semi-arid region from Brazil, using a Cobb Avian 48 broiler strain at the age of 38 and 50 weeks. We measured the following bioclimatic indexes: air temperature and relative humidity, black globe temperature and humidity, $\mathrm{CO}_{2}$ concentration and sound pressure levels at henhouse facility. Data analysis design was complete randomized in a $3 \times 3$ factorial scheme with three treatments (months) and three replications (week number of collection by month). A number of 25 climatic data were observed. Bioclimatic indexes at the most warm hours throughout the day promoted bird discomfort yet sound pressure and carbon dioxide levels were under the Brazilian standards. Even in thermal comfort zone at some hours, the productivity indexes were in compliance with those recommended by the strain creation guidebook.
\end{abstract}

KEYWORDS: ambience, thermal comfort, egg-laying, noise.

\section{DESEMPENHO DE GALINHAS PESADAS E ECLODIBILIDADE DOS OVOS NA ESTAÇÃO CHUVOSA NA REGIÃO SEMIÁRIDA BRASILEIRA}

RESUMO: As condições de conforto térmico dentro das instalações e a idade das aves afetam diretamente a produtividade de galinhas-matrizes pesadas, portanto o objetivo deste trabalho foi avaliar os índices de conforto ambiental e produtivo em matrizes de frangos de corte, em condições de inverno, na região semiárida nordestina, utilizando aves da linhagem Cobb Avian 48, com idade entre 38 e 50 semanas. Os índices bioclimáticos mensurados foram a temperatura e a umidade relativa do ar, o índice de temperatura de globo negro e a umidade, a concentração de $\mathrm{CO}_{2}$ e o nível de pressão sonora dentro das instalações. Para a análise dos dados, foi utilizado o delineamento inteiramente casualizado, com arranjo fatorial 3x3, com três tratamentos (meses) e três repetições (números de semana de coleta em cada mês). Em cada dia da semana, foram coletados 24 dados climáticos. Os índices bioclimáticos nos horários mais quentes do dia propiciaram desconforto às aves, e o nível de pressão sonora e o dióxido de carbono ficaram dentro do estabelecido pelas normas brasileiras. Mesmo fora da zona de conforto térmico em alguns horários, os índices produtivos encontrados estiveram coerentes com as recomendações técnicas do manual de criação da linhagem.

PALAVRAS-CHAVE: ambiência, conforto térmico, postura, ruído.

\footnotetext{
${ }^{1}$ Extraído da Dissertação de Mestrado da segunda autora. Projeto financiado pela CNPq.

${ }^{2}$ Zootecnista, Prof. Dr., Unidade Acadêmica de Engenharia Agrícola da UFCG, Campina Grande - PB, Fone: (83) 2101-1486, dermeval@deag.ufcg.edu.br

${ }^{3}$ Zootecnista, Mestre em Engenharia Agrícola, laptota@yahoo.com.br

${ }^{4}$ Eng ${ }^{0}$ Agrícola, Prof. Dr., Unidade Acadêmica de Engenharia Agrícola da UFCG, Campina Grande - PB, Fone: (83) 2101-1482, wallace@deag.ufcg.edu.br

${ }^{5}$ Zootecnista, Profa. Dra., IFET/PE, mercia_dmf@yahoo.com.br.

${ }^{6}$ Eng ${ }^{\underline{0}}$ Agrícola, Prof. Dr., Unidade Acadêmica de Engenharia Agrícola da UFCG, Campina Grande - PB. Fone: (83) 2101-1490, lopesneto@deag.ufcg.edu. 


\section{INTRODUCTION}

The Brazilian semi-arid region presents two distinct seasons: one of them when high temperatures and low humidity are recorded and the other with mild temperatures and rains. The broiler and egg-layer hen breeding business are growing for many reasons such as breeding system technical knowledge and warmer weather conditions (JÁCOME et al., 2007; TRINDADE et al., 2007; VITORASSO \& PEREIRA, 2009; FURTADO et al., 2011), associated to market increase due to local population purchasing power enhancement.

In egg-laying hen production analysis, there is not only animal performance and egg quality worries (ALVES et al., 2007; BARBOSA et al., 2012), but also are more and more common: animal welfare (PEREIRA et al., 2007) and behavior (PEREIRA et al., 2005), as worker welfare and health. CARVALHO et al. (2012), assessing ergonomic conditions for broiler henhouse workers, reported that some activities in henhouse buildings may be considered harmful to worker health, and the ammonia concentration in the morning (9 a.m.) surpassed allowed levels.

Chicken genetic improvement aiming to reach higher growing speed, associated to nutrition, management, sanity, and ambience improvements generate a zootechnically effective bird with meat and egg production capacity allowing intensive breeding, in industrial scale which a large number of animals can be housed, but high production brings problems related to rearing environment (MENEGALI et al., 2009; FURTADO et al., 2010; 2011) and animal welfare, which has been more and more a very important concern of customers and producers (ALVES et al., 2007; ROCHA et al., 2008a).

In this context, comfort inside buildings must be highlighted (ABREU \& ABREU, 2011), mainly in arid and semi-arid locations, taking into account every environment such as thermal (temperature, humidity, wind speed and others), acoustic (noises), air (gases, dust and fungus) and social. In tropical countries such as Brazil, intensive poultry production must be enhanced; so, in this purpose, buildings should be improved; and, in some cases, change management to overcome deleterious effect of critical environmental factors (VITORASSO \& PEREIRA, 2009).

Warm climate regions do not always have adequate environmental conditions to egg production and quality, where production and egg quality falls are usual, being expressed by lower hatching rate and conservancy (TRINDADE et al., 2007), and fowls housed in adverse weather conditions have less productivity and lower quality eggs (ALVES et al., 2007), which are also influenced by age where older birds produce low quality eggs than younger ones (BARBOSA et al., 2012).

Therefore, this research aimed to assess environmental indexes (temperature, air relative humidity, black globe temperature and humidity), $\mathrm{CO}_{2}$ concentration, sound pressure levels, and productive performance (feed consumption, egg production, feed conversion, and hatching rate) in broiler breeder henhouse during winter period in a semi-arid region of Paraiba State.

\section{MATERIAL AND METHODS}

Research was performed in Azevém Ltda. Poultry Farm, located in Boa Vista city, semi-arid region of Paraiba State, sited between $7^{\circ} 09^{\prime} 03.7^{\prime \prime}$ and $7^{\circ} 22^{\prime} 19.7^{\prime \prime}$ south latitude and $36^{\circ} 05^{\prime} 25.6^{\prime \prime}$ and $36^{\circ} 22^{\prime} 22.8^{\prime \prime}$ west longitude geographical coordinates. According to Köeppen classification, the climate is Bsh' type - semi-arid and warm, with low rainfall annual average (416 mm), irregular rainfall regime, dry season of up to eight months and short rain season, which low temperatures are recorded associated with higher air humidity levels. The average annual temperature is about $23.4{ }^{\circ} \mathrm{C}$ at a $450 \mathrm{~m}$ altitude.

Experiment was carried out during winter period of June to August 2011. Broiler breeders of Cobb Avian $48^{\circledR}$ strain were used in an amount of 12,895 birds (11,723 females and 1,172 males), having an average age of 38 weeks in the trial beginning and 50 weeks in the end. The ratio female and male was kept all experiment. Fowls were housed in a henhouse with $200 \mathrm{~m}$ length and $14 \mathrm{~m}$ 
width, in a total area of $2,800 \mathrm{~m}^{2}$, in a longitudinal axis East-West, conventional masonry walls, north and south wire mesh frontage with rubber fabric, masonry 0,2 m small wall, $3.5 \mathrm{~m}$ ceiling height, asbestos cement pitched roof, $1 \mathrm{~m}$ eaves.

Poultry building was divided into four $50 \mathrm{~m}$ long and $14 \mathrm{~m}$ wide boxes with 18 nests each, separated by a $2.8 \mathrm{~m}$ high steel screen. Cooling system was adiabatic and evaporative type with positive forced ventilation in a total of 48 ventilation fans with an average flow of $120 \mathrm{~m}^{3} \mathrm{~min}^{-1}$ each, being 12 fans per box and arranged crosswise to the building length. In the building a lighting program was adopted performing $16 \mathrm{~h}$ with light and $10 \mathrm{~h}$ with no light (14L: 10N).

Misting system was composed by PVC pipes, installed at 5 lines distributed throughout the building with mist nozzles spaced each $2 \mathrm{~m}$ in the lines, in a total of 98 nozzles. Every time temperature exceeded $24{ }^{\circ} \mathrm{C}$ the system was turned on and when air humidity reached $80 \%$ turned off, being used whenever necessary. During operation, curtains remained open, being closed together with system shutdown.

Carbon dioxide $\left(\mathrm{CO}_{2}\right)$ data collection was made at $0.3 \mathrm{~m}$ height point (bird breathing level) and at $1.6 \mathrm{~m}$ height (human breathing level), using a Testo 535 sensor, and infrared principle with $1 \mathrm{ppm}$ resolution and 0 to $10,000 \mathrm{ppm}$ measurement range. Sound pressure (noises) was measured using a decibel meter together with $\mathrm{CO}_{2}$ levels at $1 \mathrm{~m}$ height at 40 point throughout the building (10 per box), in other words, spaced $5 \mathrm{~m}$ apart from each other. Data were weekly collected every one hour from 8 am to 4 pm during all experiment period.

The climatic variables, temperature and air relative humidity, were read for all experimental period through sensors installed in the geometrical center of each box at $0.5 \mathrm{~m}$ high from floor. Every sensor was connected to a datalogger set up to record data each 20 minutes; and hourly averages being calculated afterwards. Sensors were raised to avoid animal access to equipment and impair them interfering in the results. The hourly averages for climatic variables were used to calculate black globe temperature and humidity as proposed by BUFFINGTON et al. (1977).

Feed consumption records were daily obtained to supply mechanized in equal amounts twice a day at 5: 30 am and 5:30 pm. The feed diet was based on table provided to Coob strain (COBB, 2008) and water supplied ad lib through mechanized nipple drinkers.

Egg production rate manually collected was obtained through relation between number of housed fowls and number of produced eggs (including broken, deformed, and cracked eggs); feed conversion made by division of feed consumption by production in egg dozen $(\mathrm{kg} / \mathrm{dz})$, and hatching rate through relation of number of incubated eggs and born chicks (monthly).

It was used a complete randomized design in $3 \times 3$ factorial scheme with three treatments (months - June, July and August) and three replications (week number of collection by month) for climatic data analysis. Variance and regression analysis was used to evaluate data. After, the Tukey test was applied to compare averages at the level of $5 \%$ probability. In what concerns to zootechnical performance, an entirely randomized design with three treatments (moths of the year) and 12 replications (week number). Fowls were at peak egg production. And data were processed through ASSISTAT 7.5 software (ASSISTAT, 2010).

\section{RESULTS AND DISCUSSION}

Carbon dioxide concentration average values inside henhouse building did not presented significant differences among time and month, reaching maximum value at $1.7 \mathrm{~m}(444 \mathrm{ppm})$ and minimum at $0.3 \mathrm{~m}$ (486.5 ppm). These numbers are under maximum tolerance limit to human by Regulatory Norm $\mathrm{n}^{\mathrm{o}} 15$ of Ministry of Labor of Brazil that is 2,500 ppm (BRASIL, 1996), as also advocated by the Animal Welfare Commission of European Union, which set 3,000 ppm at $0.3 \mathrm{~m}$ height. 
This low $\mathrm{CO}_{2}$ concentration could be justified by mechanic ventilation applied to the henhouse with its architectural features. Low values were also found by VIGODERIS et al. (2010) in laying hen facilities, evaluating minimum ventilation system in broiler poultry houses, concluded that buildings kept gas concentrations, such as $\mathrm{CO}_{2}$, within the established limit by the norm, not reaching non-injurious values.

Similar results were also reported by MENEGALI et al. (2009), who analyzed thermal environment and gas concentration in broiler poultry houses in heating period. These authors describe that $\mathrm{CO}$ and $\mathrm{CO}_{2}$ inside buildings were within the acceptable limits for a good breeding stock development. CARVALHO et al. (2011) evaluating air quality for first broiler housing, at varied minimum ventilation system and building typology (blue, dark and conventional house), concluded that used ventilation was not enough to assure air quality in the facilities.

According to NÄÄS et al. (2007), opening control is fundamental, once ventilation present relevant function, mainly for hygienic reasons, renewing air to avoid undesirable gas concentration increase inside buildings.

In the case of noises (Figure 1), it was observed higher sound levels in the morning period, what may be explained by the morning laying behavior and operator movements to collect eggs, manually made, what induced animal hustle, and also fan noises during the day time.

The peak hour was at $8 \mathrm{am}$, when sound level reached $81.77 \mathrm{~dB}$ and the lower values were at $3 \mathrm{pm}$, reaching $70.75 \mathrm{~dB}$, being for all time and months, the sound pressure levels were under tolerance limit related to worker exposure to impact noise peaks and intensity. This limit, according to BRASIL (1996) is $85 \mathrm{~dB}$ (A), for $8 \mathrm{~h}$ workers not being necessary the use of earpiece. CARVALHO et al. (2012) assessing sound level in fowl farming activities observed that some activities such as firewood cut got values over the limit, being harmful to worker health.

The observed peaks at $8 \mathrm{pm} ; 1 \mathrm{pm}$, and $4 \mathrm{pm}$ are due to cooling system triggering and birds get agitated as workers move around the building for egg collection, made six times a day, three times in the morning and three in the afternoon.

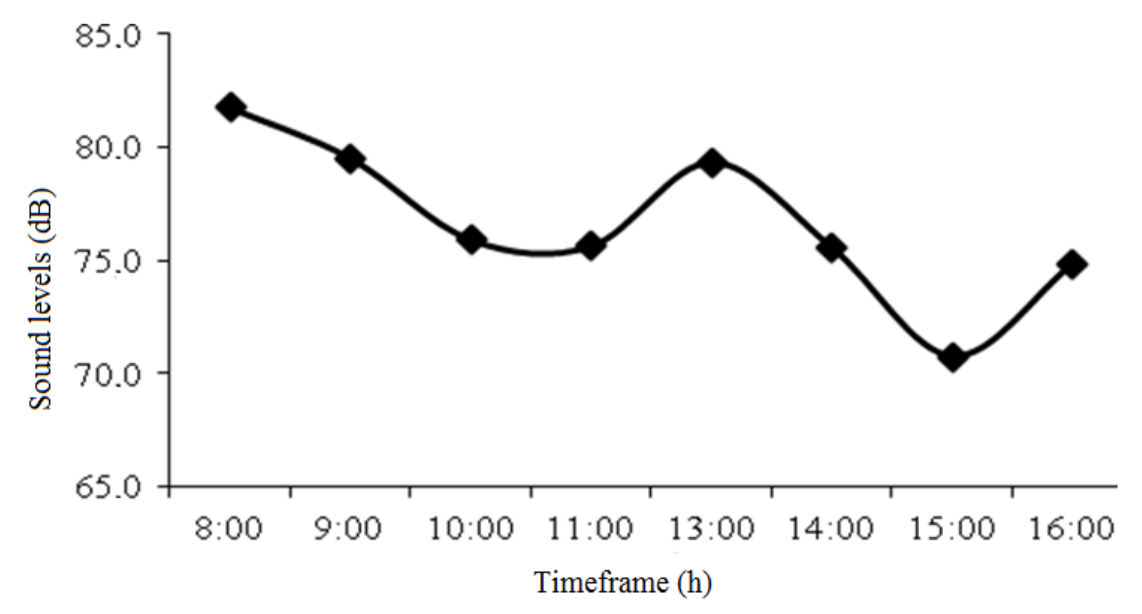

FIGURE 1. Average sound levels inside building.

FURTADO et al. (2011) observed this trend when evaluating sound levels in the same location of the present research, i. e. in the morning time there was higher noise levels as fans, foggers and worker movement.

PEREIRA et al. (2007) surveying three broiler breeder hen strains behavior under varied temperature conditions and observed that all strains tend to visit nest in the morning time, generating more noise in henhouse. The main feed supply is made in the morning, according to PEREIRA et al. (2005), the food presence is a preponderant factor in bird behavior analysis, once 
provided increase aggressive behavior among animals, mainly for generating competition for food and space boosting noises inside the facility.

In this research, the sound levels were similar to those found by TRINDADE et al. (2006) and FURTADO et al. (2011), who assessed sound pressure in henhouses with birds at varied age levels in a Brazilian semi-arid region, concluding that they were in accordance with actual law. Correlating $\mathrm{CO}_{2}$ level and sound pressure inside facility, it was possible to notice that air quality inside the building was within the standard for animal welfare, what was similar to VITORASSO \& PEREIRA (2009) research, who evaluated egg-laying facilities in São Paulo State; they found an air quality also within the standard especially for building terms.

It is possible to observe, in Figure 2, that average environment temperature (ET) was higher in June for all day hours and lower in August from midnight to 8 am and from $6 \mathrm{pm}$ to midnight. It was also noted that in June and July, the lowest ET values were recorded at 5 am, while in August, it was checked at $4 \mathrm{~mm}$, gradually added up to maximum values between 12 to $2 \mathrm{pm}$, and decreasing until the day end.

As ABREU \& ABREU (2011) cited, for a maximum productive performance, it is needed to ensure thermo neutral environment, which for adult birds is between 18 and $28{ }^{\circ} \mathrm{C}$. Temperature above $27^{\circ} \mathrm{C}$ can promote varied productive losses, as reduced shell thickness, increased risk of contamination by salmonella (Salmonella typhimurium), weight loss of constituent components, and lesser egg-laying (BARBOSA FILHO et al., 2006).

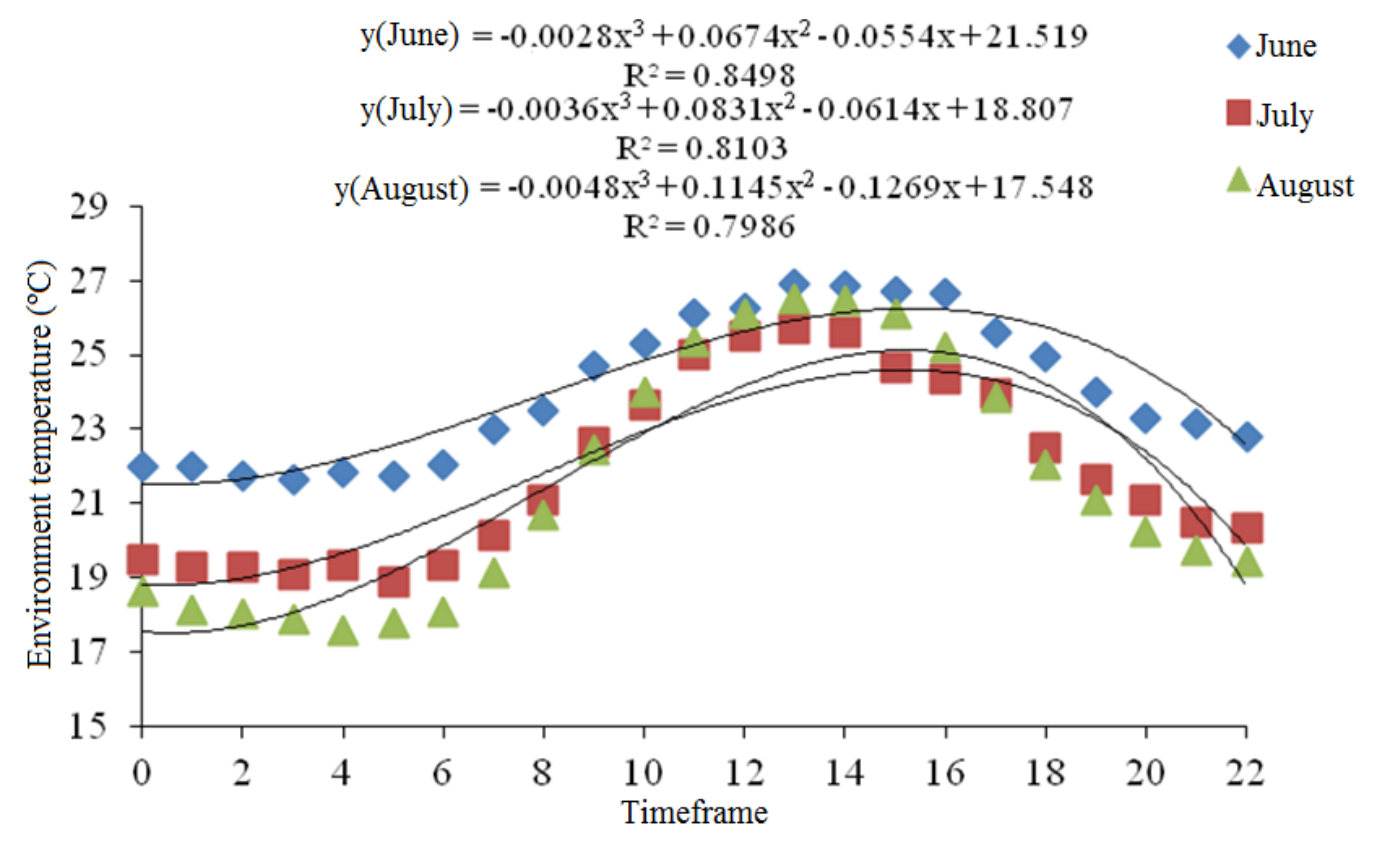

FIGURE 2. Average temperature values $\left({ }^{\circ} \mathrm{C}\right)$ inside buildings.

Maintaining poultry production in thermal comfort zone (TCZ) should be a constant concern, and it is observed that during the rainy season, when milder temperatures are registered at the location, averages were found in the hottest day, above TCZ, subjecting birds to heat stress, and this temperature at all analyzed hours and months, did not reach the upper critical temperature for this animal rank, which according BAETA \& SOUZA (2010) is $34^{\circ} \mathrm{C}$. FURTADO et al. (2011) performing experiment in same region, but in summer period, describe a more intense thermal discomfort situation for an egg-laying facility, emphasizing that from 10 am to $3 \mathrm{pm}$, ET was above $32{ }^{\circ} \mathrm{C}$ influencing fowl performance.

Average values of relative humidity $(\mathrm{RH})$ in different months and hours remained stable from 0 to $4 \mathrm{pm}$ (Figure 3); and from the early morning hours (6 am) until early afternoon (2 am) values decreased then rise again from $4 \mathrm{pm}$. The high $\mathrm{RH}$ average values found at night hours are justified 
by the rainy season, in which survey was conducted, when a higher water concentration is in atmosphere, but on average, $\mathrm{RH}$ values remained in comfort and recommended range, as cited by MEDEIROS et al. (2005), at between 50 and 80\%, but at certain times, above values were observed, mainly taking as basis quotes by ABREU \& ABREU (2011), mentioning as air ideal relative humidity to adult birds the range between 60 to $70 \%$.

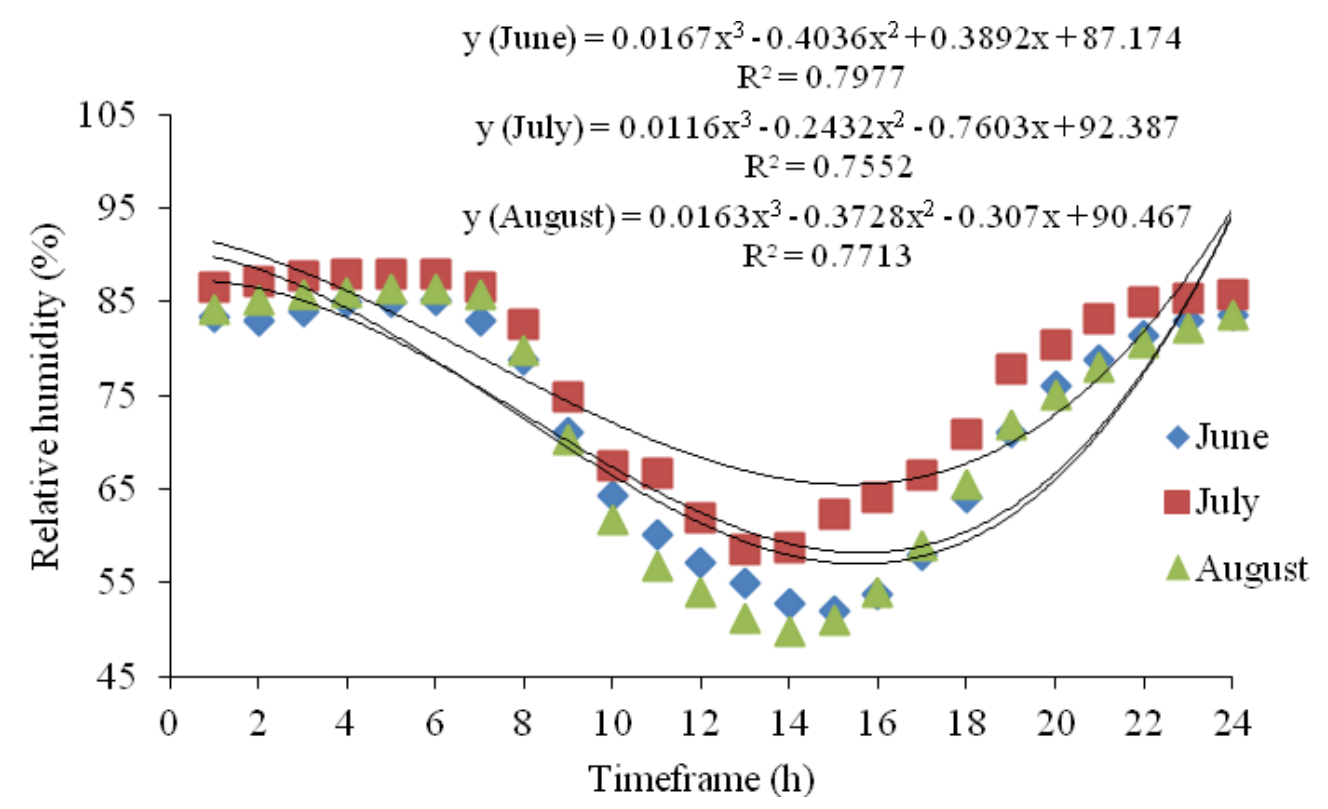

FIGURE 3. Relative humidity average values (\%), each 2 hours, observed in June, July, and August.

As birds are species endowed with few sweat glands, whether in high temperature environment, remove heat in a latent state, mainly by evaporation, which occurs in skin and respiratory tract, and the factor that most influences heat dissipation by evaporation is the air amount expelled by fowls (ABREU \& ABREU, 2011), what depends on environment temperature and especially relative humidity.

The dark globe temperature and humidity (DGTH) showed higher values between 12 and $2 \mathrm{pm}$ (Figure 4), and lowest in early morning and evening due to temperature and solar radiation range in facility. The values found in June were higher than in other months being because in this month temperature in the semi-arid region is still high and, for DGTH calculation, the highest coefficient is admitted to air temperature (0.7).

The highest value was 75.1 in June, and the lowest 64.8 in August. The highest value is near DGTH upper limit of 75.0 established by SOUZA et al. (2002) for environmental comfort condition indicating that at between 12 and $4 \mathrm{pm}$, in June, the environment was at the thermal stress threshold by high temperature (upper limit of mild thermal comfort zone).

JÁCOME et al. (2007) e FURTADO et al. (2011), assessing fowls in northeastern semi-arid region, found DGTH increasing values until $2 \mathrm{pm}$ then decreasing from this time, being from 12 to $2 \mathrm{pm}$ the most critical of the day, occurring animal discomfort. 


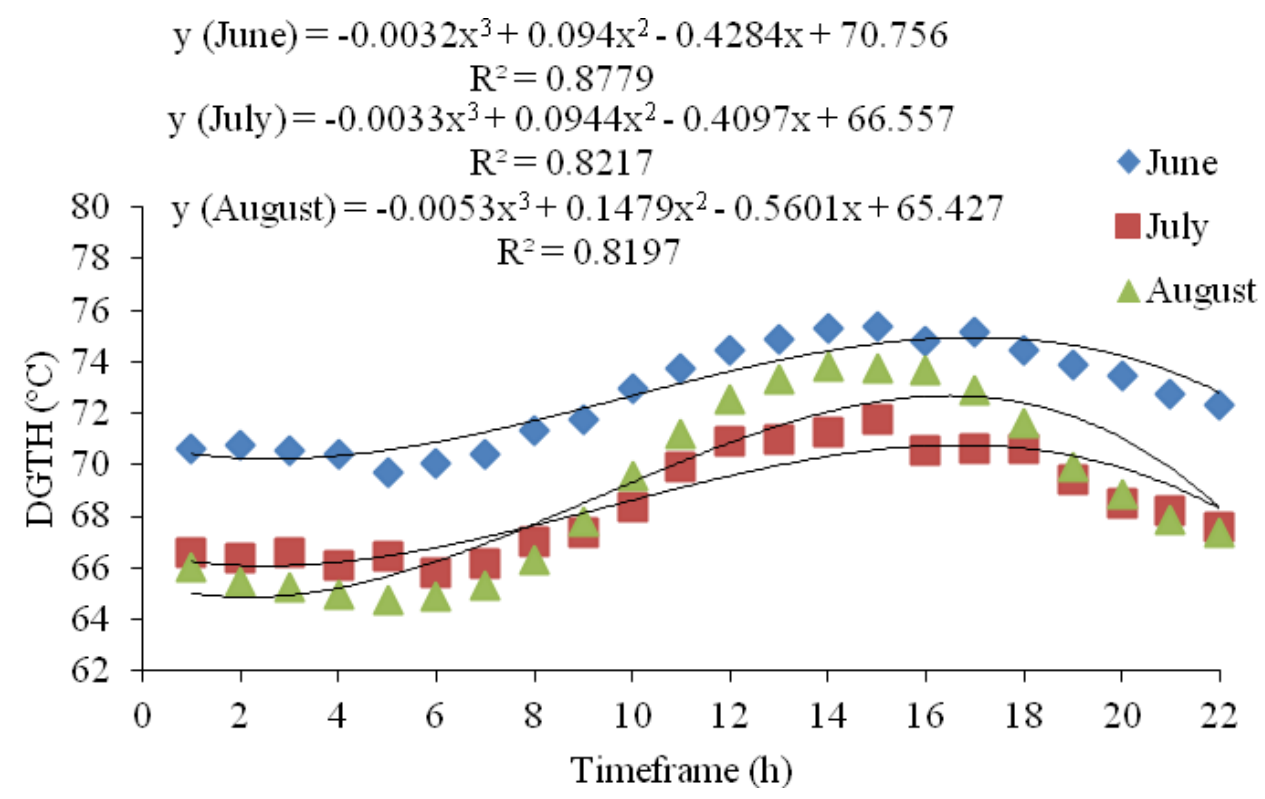

FIGURE 4. DGTH average values, each 2 hours, observed in June, July, and August.

Animal feed intake showed significant differences $(\mathrm{P}<0.05)$ among studied months (Table 1$)$, when the highest consumption occurred in June and the lowest in August. As temperature decreased, there is a trend to increase food consumption, i.e. to compensate production, especially at night, which did not occur in this experiment, when in colder months there was intake reduction and also smaller temperature range, i.e., in June, amplitude was 5.26, in July 6.8, and in August this $8.93{ }^{\circ} \mathrm{C}$.

TABLE 1. Feed intake, egg-laying rate, feed conversion, and hatching rate.

\begin{tabular}{ccccc}
\hline Months & $\begin{array}{c}\text { Feed intake } \\
\text { (g/bird/day) }\end{array}$ & $\begin{array}{c}\text { Egg-laying rate } \\
(\%)\end{array}$ & Feed conversion & $\begin{array}{c}\text { Hatching rate } \\
\text { (\%) }\end{array}$ \\
\hline June & $168.0 \mathrm{~A}$ & $74.5 \mathrm{~A}$ & $2.7 \mathrm{~B}$ & $90.6 \mathrm{~A}$ \\
July & $165.1 \mathrm{~B}$ & $73.4 \mathrm{~B}$ & $2.8 \mathrm{~A}$ & $95.3 \mathrm{~A}$ \\
August & $160.3 \mathrm{C}$ & $70.0 \mathrm{C}$ & $2.8 \mathrm{~A}$ & $85.5 \mathrm{~B}$ \\
\hline
\end{tabular}

Averages followed by same letter in the row do not differ to each other by Tukey test at $5 \%$ probability.

Analyzing egg-laying rate (Table 1), it can be seen that the greatest percentage was found in June $(74.5 \%)$ when occurred the highest feed intake and temperature was higher with a shorter temperature range than July and August. Another factor that interferes with production is bird age, which tends to decline in older birds (FURTADO et al., 2011).

RIBEIRO et al. (2008) in studies with semi-heavy laying hens, at the end of the first and during the second laying cycle, with sodium level of 0.18 and $0.23 \%$, mention values of egg production of $76.20 \%$ and $71.29 \%$, respectively.

Egg-laying rates in June and July were similar to those described by FURTADO et al. (2010), analyzing total egg production from different age hens, inferred that the birds at 35 and 48 weeks had 74.83 and $76.86 \%$ of egg production, respectively. It is observed in feed conversion, there is similarity between July and August (Table 1); however these months differed statistically from the value obtained in June.

This range among months may be related to temperature variations. As in June, there was less need for body temperature maintenance, due to the higher temperature, nutrients absorbed by animals were more suited to production, while in other months, colder ones, part of nutrients have been directed to maintenance. These values are much higher than those found by ROCHA et al. (2008b) who studied the effect of grading eggs from broiler breeders found a 1.70 feed conversion 
rate, demonstrating that there were differences among strains regarding this factor as well as many productive indexes.

It is found that hatching rate was lower in August (85.6\%), differing statistically $(\mathrm{P}<0.05)$ of June (90.6\%) and July (95.3\%), which did not differ to each other (Table 1). The hatchability reduction in August can be justified for colder temperatures as well as hen age, corroborating to BARBOSA et al. (2012), cited that as the older hen batch there is a simultaneous reduction in the internal and external egg quality, where younger hen eggs have a lower specific weight, less pore number, avoiding heat losses or embryo dehydration, shells are thicker, consequently with higher strength, which facilitates handling what improves egg hatchability in younger hens.

FURTADO et al. (2011) in a study in Paraiba semiarid region, using birds with 35, 48 and 66 weeks, found no differences in hatching rate, which stood at an average of $95.68 \%$, which is higher than those reported in this study, in which bird age did not affect hatching rate.

The percentage of cracked eggs (Table 2) was lower in July and percentage of broken and deformed eggs was similar in all months. The largest percentage of cracked eggs in June and August may be related to shell thickness, since according to ALVES et al. (2007) and BARBOSA et al. (2012), climate changes and factors related to bird age and metabolism are involved in the egg formation and shell thickening.

TABLE 2. Percentage of cracked, broken, and deformed eggs in evaluated months.

\begin{tabular}{cccc}
\hline Months & Cracked (\%) & Broken (\%) & Deformed (\%) \\
\hline June & $1.28 \mathrm{~A}$ & $0.23 \mathrm{~A}$ & $0.75 \mathrm{~A}$ \\
July & $0.98 \mathrm{~B}$ & $0.18 \mathrm{~A}$ & $0.60 \mathrm{~A}$ \\
August & $1.32 \mathrm{~A}$ & $0.23 \mathrm{~A}$ & $0.75 \mathrm{~A}$ \\
\hline Average & 1.19 & 0.21 & 0.70 \\
\hline
\end{tabular}

The greatest egg loss was checked for cracking, other than quoted by ALVES et al. (2007), who studied Hy-Line W36 and Isabrow fowl strains in the cage and floor system, found a cracked egg percentage laid on floor of 0.50 and $0.80 \%$ and broken eggs of 1.08 and $1.42 \%$, respectively, which may be associated with the used rearing system.

PILOTTO et al. (2010), studying the effect of nest location changes for laying eggs from broiler breeders, observed an average percentage of cracked eggs of $0.57 \%$ and $1.20 \%$ for manual and automated nest, respectively, noting that this increased cracked egg percentage in automated nest was due to the nest structure, with very leaned bed, narrow conveyor belt making eggs to roll out of nest very quickly, colliding with other already deposited eggs on belt edge.

BARBOSA et al. (2012) evaluated eggshell quality of broiler breeders of different ages, observed that older breeders have a lower egg quality than younger ones, and eggshell membrane play an important role in its structure.

\section{CONCLUSIONS}

Bioclimatic indexes, especially during warmer periods of the day, propitiated bird discomfort, and the sound pressure level and carbon dioxide concentrations were within established by Brazilian and international standards.

The lower feed intake, egg production rate and hatching values were recorded in August, considered the coldest month and birds in older age.

\section{REFERENCES}

ABREU, V. M. N.; ABREU, P. G. Os desafios da ambiência sobre os sistemas de aves no Brasil. Revista Brasileira de Zootecnia, Viçosa, v.40, p.1-14, 2011. Suplemento Especial. 
ALVES, S. P.; SILVA, I. J. O.; PIEDADE, S. M. S. Avaliação do bem-estar de aves poedeiras comerciais: efeitos do sistema de criação e do ambiente bioclimático sobre o desempenho das aves e a qualidade de ovos. Revista Brasileira de Zootecnia, Viçosa - MG, p.1388-1394, 2007.

ASSISTAT. Programa de análise estatística. Versão Beta 7.5. Campina Grande: Departamento de Engenharia Agrícola, CTRN UFCG, 2010.

BAÊTA, F. C.; SOUZA, C. F. Ambiência em edificações rurais - Conforto animal. 2.ed. Viçosa MG: UFV, 2010. 269 p.

BARBOSA FILHO, J. A. D.; SILVA, M. A. N.; SILVA, I. J. O.; COELHO, A. A. D. Egg quality in layers housed in different production systems and submitted to two environmental conditions. Brazilian Journal of Poultry Science, Campinas, v.8, n.1, p.23-28, 2006.

BARBOSA, V. M.; BAIÃO, N. C.; MENDES, P. M. M.; ROCHA, J. S. R.; POMPEU, M. A.; LARA, L. J. C.; MARTINS, N. R. S.; NELSON, D. L.; MIRANDA, D. J. A.; CUNHA, C. E.; CARDOSO, D. M.; CARDEAL, P. C. Avaliação da qualidade da casca dos ovos provenientes de matrizes pesadas com diferentes idades. Arquivo Brasileiro de Medicina Veterinária e Zootecnia, Belo Horizonte, v.64, n.4, p.1036-1044, 2012.

CARVALHO, C. C. S.; SOUZA, C. M.; TINÔCO, I. F. F.; VIEIRA, M. F. V.; MENEGALI, I.; SANTOS, C. R. Condições ergonômicas dos trabalhadores em galpões de frangos de corte durante a fase de aquecimento. Revista Brasileira de Engenharia Agrícola e Ambiental, Campina Grande, v.16, n.11, p.1243-1251, 2012.

BRASIL. Ministério do Trabalho. NR-15. Portaria nº 3.214 de 8 de junho de 1978: Normas regulamentadoras relativas à segurança e medicina do trabalho. In: MANUAL de Legislação de Atlas de Segurança e Medicina do Trabalho. 33.ed. São Paulo: Atlas, 1996. 523 p.

BUFFINGTON, C. S.; COLLAZO, A.; CANTON, G. H. Black globe humidity confort index for dair cows. St Joseph: American Society of Agricultural and Biological Engineers, 1977. 19 p.

CARVALHO, T. M. R.; MOURA, D. J.; SOUZA, Z. M.; SOUSA, G. S.; BUENO, L. G. G. Qualidade da cama e do ar em diferentes condições de alojamento de frangos de corte. Pesquisa Agropecuária Brasileira, Brasília, v.46, n.4, p.351-261, 2011.

COBB - Manual de Manejo de Frangos de Corte - WWW VANTRESS COM. Revisto em 2008. www.aviculturaintelegente.com.br. Acesso em: 26 maio 2014.

FURTADO, D. A.; MOTA, J. K. M.; NASCIMENTO, J. W. B.; SILVA, V. R.; TOTA, L. C. A. Produção de ovos de matrizes pesadas criadas sob estresse térmico. Revista Brasileira de Engenharia Agrícola e Ambiental, Campina Grande, v.15, n.7, p.748-753, 2011.

FURTADO, D. A.; ROCHA, H. P.; NASCIMENTO, J. W. B.; SILVA, J. H. V. Índices de conforto térmico e concentração de gases em galpões avícolas no semiárido paraibano. Engenharia Agrícola, Jaboticabal, v.30, n.6, p.993-1002, 2010.

JÁCOME, I. M. T. D.; FURTADO, D. A.; LEAL, A. F.; SILVA, J. V. H.; MOURA, J. F. P. Avaliação de índices de conforto térmico de instalações para poedeiras no nordeste do Brasil. Revista Brasileira de Engenharia Agrícola e Ambiental, Campina Grande, v.11, n.5, p.527-531, 2007.

MEDEIROS, C. M.; BAETA, F. da C.; OLIVEIRA, R. F. M. de; TINOCO, I. F. F.; ALBINO, L. F. T.; CECON, P. R. Efeitos da temperatura, umidade relativa e velocidade do ar em frangos de corte. Engenharia na Agricultura, Viçosa - MG, v.13, n.4, p.277-286, 2005.

MENEGALI, I.; TINÔCO, I. F. F.; BAÊTA, F. C.; CECON, P. C.; GUIMARÃES, M. C. C.; CORDEIRO, M. B. Ambiente térmico e concentração de gases em instalações para frangos de corte no período de aquecimento. Revista Brasileira de Engenharia Agrícola e Ambiental, Campina Grande, v.13, p.984-990, 2009. Suplemento. 
NÄÄS, I. A.; MIRAGLIOTTA, M. Y.; BARACHO, M. S.; MOURA, D. J. Ambiência aérea em alojamento de frangos de corte: poeira e gases. Engenharia Agrícola, Jaboticabal, v.27, n.2, p.326335, 2007.

PEREIRA, D. F.; NÃ̃̃S, I. A.; ROMANINI, C. E. B.; SALGADO, D. D.; PEREIRA, G. O. T. Indicadores de bem-estar baseados em reações comportamentais de matrizes pesadas. Engenharia Agrícola, Jaboticabal, v.25, n.2, p.308-314, 2005.

PEREIRA, D. F.; SALGADO, D. D.; NÃ̃̃S, I. A.; PENHA, N. L. J.; BIGHI, C. A. Efeitos da temperatura do ar, linhagem e período do dia nas frequências de ocorrências e tempos de expressão comportamental de matrizes pesadas. Engenharia Agrícola, Jaboticabal, v.27, n.3, p.596-610, 2007.

PILOTTO, F.; RIBEIRO, A.M.L.; CARGNELUTTI FILHO, A.; KLEIN, V.A. Efeito da transformação do ninho manual modelo holandês em mecânico na postura de ovos de cama em matrizes de frango de corte. Revista Brasileira de Zootecnia, Viçosa - MG, v.39, n.10, p.2310-2314, 2010.

RIBEIRO, M. L. G.; SILVA, J. H. V.; ARAUJO J. A.; MARTINS T. D. D.; COSTA, F. G. P.; GIVISIEZ P. E. N. Exigência de sódio para poedeiras no final do primeiro ciclo e durante o segundo ciclo de postura. Revista Brasileira de Zootecnia, Viçosa - MG, v.37, n.7, p.1257-1264, 2008.

ROCHA, J. S. R.; LARA, L. J. C.; BAIÃO, N. C. Produção e bem-estar animal aspectos éticos e técnicos da produção intensiva de aves. Ciência Veterinária nos Trópicos, Recife, v.11, p.49-55, 2008a (suplemento 1).

ROCHA, J. S. R.; LARA, L. J. C.; BAIÃO, N. C.; CANÇADO, S. V.; TRIGINELLI, M. V.; LEITE, J. F. C. Efeito da classificação dos ovos sobre a uniformidade, o desempenho e o rendimento de abate de frangos de corte. Arquivo Brasileiro de Medicina Veterinária e Zootecnia, Belo Horizonte, v.60, n.5, p.1181-1187, 2008b.

SOUSA, C. F.; TINÔCO, I. F. F.; BAÊTA, F. C.; FERREIRA, W. P. M.; SILVA, R. S. Avaliação de materiais alternativos para confecção do termômetro de globo. Ciência e Agrotecnologia, Lavras, v.26, n.1, p.157-164, 2002.

TRINDADE, J. L.; FURTADO, D. A.; NASCIMENTO, J. W. B. DO; LEAL, A. F.; LOPES NETO, J. P. Avaliação dos níveis de pressão sonora em galinhas poedeiras no semiárido paraibano. Revista Brasileira de Ciência Avícola, Campinas, n.8, p.189, 2006. Suplemento especial.

TRINDADE, J. L.; NASCIMENTO, J. W. B.; FURTADO, D. A. Qualidade do ovo de galinhas poedeiras criadas em galpões no semiárido paraibano. Revista Brasileira de Engenharia Agrícola e Ambiental, Campina Grande, v.11, n.6, p.652-657, 2007.

VIGODERIS, R. B.; CORDEIRO, M. B.; TINÔCO, I. F. F.; MENEGALI, I.; SOUZA JÚNIOR, J. P.; HOLANDA, M. C. R. Avaliação do uso de ventilação mínima em galpões avícolas e de sua influência no desempenho de aves de corte no período de inverno. Revista Brasileira de Zootecnia, Viçosa - MG, v.39, n.6, p.1381-1396, 2010.

VITORASSO, G.; PEREIRA, D. Análise comparativa do ambiente de aviários de postura com diferentes sistemas de acondicionamento. Revista Brasileira de Engenharia Agrícola e Ambiental, Campina Grande, v.13, n.6, p.788-794, 2009. 